\title{
Impact on the building performance of subsequently cast concrete
}

\author{
Ibrahim Baran Karasin a,*, Ercan Işık b \\ a Bitlis Eren University, Department of Civil Engineering, TR-13000, Bitlis Turkey \\ b Bitlis Eren University, Department of Civil Engineering, TR-13000, Bitlis Turkey
}

\section{ART ICLE IN FO}

Article history:

Received 12 April 2017

Received in revised form 15 May 2017

Accepted 12 June 2017

\section{Keywords:}

Concrete Class

Pushover Analys is

Building Performance

Subsequently Cast Concrete
A B S T R A C T

There are many examples about building stock grows uncontrollably and irregularly in Turkey which is called unplanned urbanization. A serious part of this building stock which is growing uncontrolled is created by the structures called " slum ". In this type of construction, the quality of the used concrete is low as well as poor workmanship. Over time, when these structures become inadequate to serve the purpose, additional floors are being constructed, either controlled or uncontrolled. In this study, it was tried to determine the effect of the concrete quality used in the later constructed floors and the concrete classes used in the original construction on the building performance. For this purpose, a 5 story reinforced concrete structure; It is aimed to determine the structural performance of the C14 and C25 concrete classes using different floors and different variations by static pushover analysis.

(C) 2017. Turkish Journal Park Academic. All rights reserved.

\section{Introduction}

Turkey, which has seismically very active geologic structure, damaged a significant part of the reinforced concrete building stock in the strong earthquakes that it experienced. Turkey has seen about 200 earthquakes of magnitude 5 and more in the last century. More than 80,000 people have lost their lives and more than 500,000 buildings have been totally destroyed or seriously damaged in earthquakes (Inel et al., 2007). The earthquakes and the consequences of these earthquakes clearly show the weakness of the reinforced concrete building stock.

Most of the structures in Turkey are constructed with reinforced concrete system. In this system, which works in harmony with steel and concrete. The concrete class used in construction phase of buildings is one of the most important parameter in terms of seismic performance. The main reason of low seismic performance of demolished reinforced concrete buildings which observed after 1967 Mudurnu, 1971 Bingöl, 1974 İzmir, 1986 Doğanşehir earthquakes is low concrete compressive strength.(Uğurlu. 2013) In Turkish Earthquake Code (2007), the effect of the concrete class on the construction performance was not overlooked and the $\mathrm{C} 20$ concrete class was obliged as the minimum usable concrete strength. (TEC, 2007)

In Turkey, especially in small settlements, the basements or ground floors of the structures due to different reasons are constructed first, and then additional floors are built after a while. A great majority of these structures do not receive engineering services. As a result, concrete is used in different qualities in the first built parts and in later built parts. This situation increases the difference of material strength between floors especially with the widespread of ready mixed concrete. Ready mixed concrete has been started to be used in the upper floors instead of manually poured concrete in the previously constructed sections. In such cases, the differences between the concrete strengths of the stories have started to reach higher values. In this study, C14 concrete is considered in the first two floors of five-story concrete structure, and C25 concrete is considered in the other stories in order to reveal the effect of difference of concrete strength between floors on structural earthquake

* Corresponding author.

Tel.: +0 5533345776

E-mail address: ibkarasin@beu.edu.tr 
behavior, In addition, for all the structures, the calculations have made separately for all bearing elements on all floors for the use of $\mathrm{C} 14$ and $\mathrm{C} 25$ concrete classes. The results obtained from calculations of 3 different situations are compared and recommendations are made.

The aim of the study is to reveal the earthquake behaviors of the buildings constructed with different concrete strengths between the floors. There are many buildings built in this way in Turkey. It is important to examine earthquake behavior of such structures.

\section{Method}

Knowing the parameters that can negatively affect the earthquake performances of the structures in the earthquake resistance structure design and taking special precautions against them will positively affect the defensive mechanism of the structures (Ișlk, 2016b). Adequate stiffness, strength and ductility are at the top of the principles considered in the designing reinforced concrete buildings under effect of earthquakes. Earthquake damages on reinforced concrete structures is primarily related to concrete strength. As the material strength increases, the stiffness of the structure also increases (Ülker et al., 2016).

Concrete is a composite material made of aggregate, cement and water. Concrete production is easy and possible around the world. Besides these, concrete production has phases such as calculation mixing, transportation, compaction and curing. Material choice and wrong applications for concrete directly effects on concrete strength. Steel production has much more strength than concrete so first damages occur on concrete material in the RC buildings after an earthquake (Işık, 2016a).

Concrete strength directly affects safety and cost for RC constructions. Concrete strength is an important factor for structural analysis. This factor directly effects on analyses. Concrete classes determining by compressive strengths, using cube and cylinder samples. The typical stressdeformation relation between different concrete is given in Figure 1.

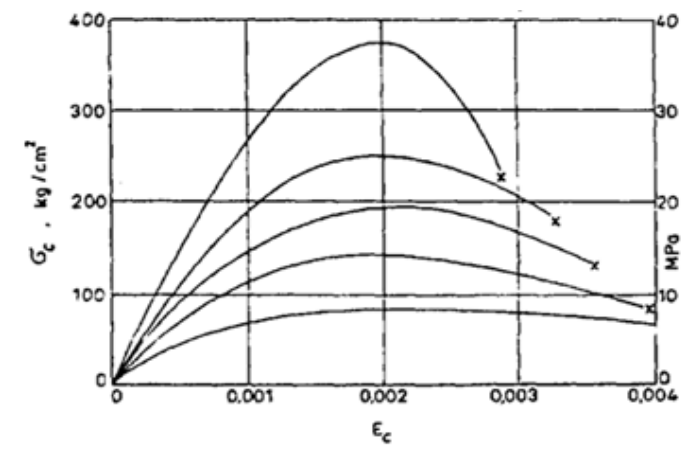

Figure 1. Stress-strain relation for different concrete classes
(Ersoy, 2007).

Pushover analysis is the common name for a type of procedure that uses simplified nonlinear static analysis (Estêvão and Oliveria, 2015). Pushover analysis is a static nonlinear analysis method in which a structure is subjected to dead loading and subjected to a systematical displacement-controlled lateral load pattern that is continuously increased through elastic and inelastic behavior until a final run is reached. Lateral load may represent the range of base shear induced by earthquake loading and its configuration may be proportional to the distribution of mass along building height, mode shapes or other practical effects (Computers and Structures, 2011).

With a performance-based design method, it is possible to quantify the damage levels that can occur under ground motion designed within the structural system components. It is checked whether this damage is under acceptable levels of damage for each relevant element. Acceptable damage limits are defined to be consistent with the performance targets predicted at various earthquake levels. (Aydınoğlu, 2007; Doran et al., 2011, Kutanis and Boru, 2015).

The main purpose of the static pushover analysis is to estimate the force and displacement demands in earthquakes which designed by static inelastic analysis and to estimate the predicted performance of the structural system by comparing these demands to the capacities at the current performance levels. The assessment is based on the evaluation of significant performance parameters such as peak displacement, inter-storey displacement, frame element deformations, and element and joint forces (Krawinkler and Seneviratna, 1998).

The pushover curve obtained from the analyses results, represents the relationship between the base shear force and the peak displacement. Building seismic weight normalized the base shear. Hence, the peak displacement is normalized to the building height to represent the shear force coefficient and the peak displacement drift, respectively. A typical example of idealized capacity curve is shown in Figure 2. 


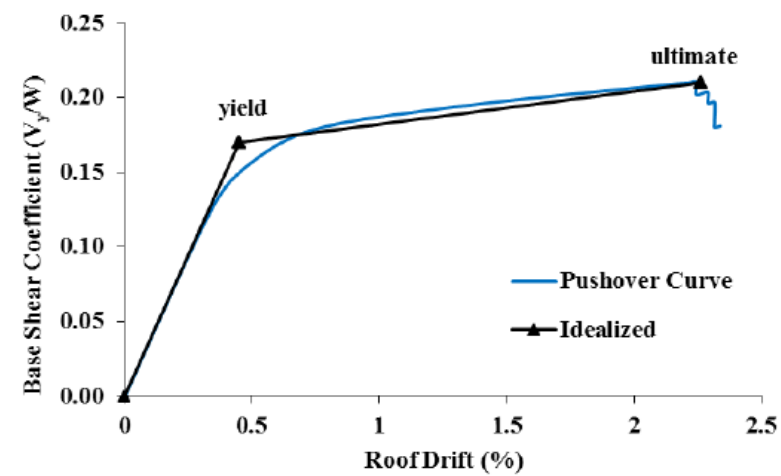

Figure 2. Typical pushover and idealized capacity curves (İnel et al., 2016)

\section{Structure Specifications}

In this study, a structure was selected as a five-story concrete reinforced concrete frame system. All floors are of equal height of $3 \mathrm{~m}$. The steel material used in the selected construction is S220. Three different calculations have been made for the case of $\mathrm{C} 14$ and $\mathrm{C} 25$ in the whole structure as concrete class, and C14 concrete class in the first two stories and C25 for other floors. The diameter of the longitudinal bars used in beams and columns is $\Phi 16$. The mold plan of the selected reinforced concrete structure is shown in Figure 3.

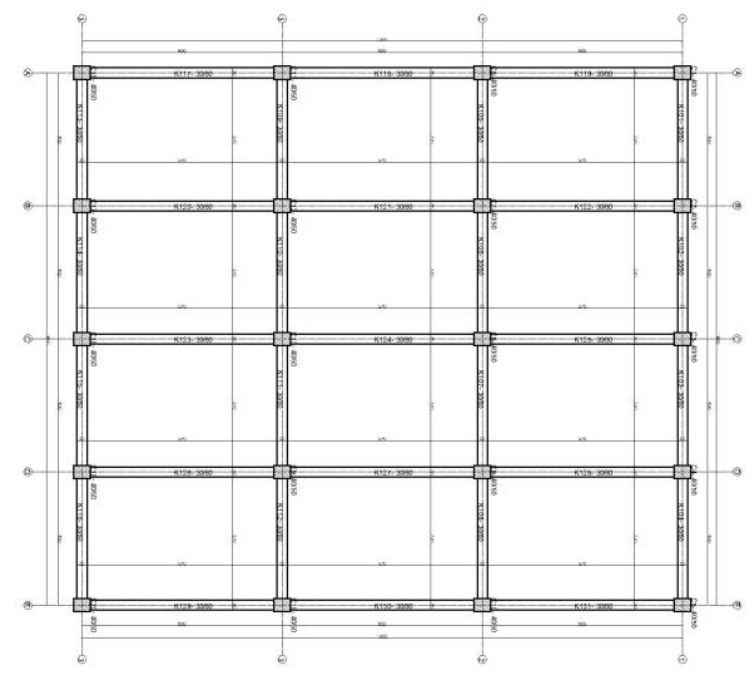

Figure 3. Formwork plan of structure

The three-dimensional model obtained from the SEISMOSTRUCT software program is shown in Figure 4.

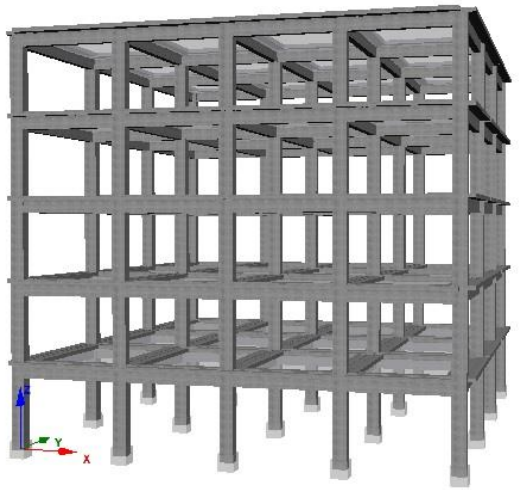

Figure 4. 3D model of investigated structure

Columns in reinforced concrete frame were chosen as $40 \mathrm{~cm}$ x $50 \mathrm{~cm}$ and beams were chosen as $25 \mathrm{~cm} \times 60 \mathrm{~cm}$. In both structural elements, $\Phi 10$ / 10 was selected as the transverse reinforcement. The column and beam cross sections used in the construction are given in Figure 5.
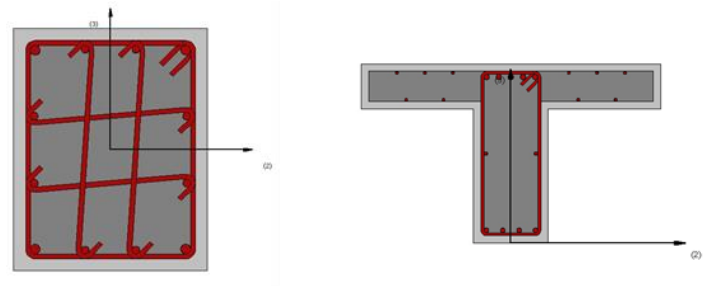

Figure 5. Column and beam cross-sections

\section{Analysis Results}

The Seismostruct software program was used for calculations. The maximum peak displacement values and deformation conditions are calculated separately for the $\mathrm{X}$ and $Y$ directions. Figure 6 shows the deformation conditions in case of using C14 concrete class in the studied structure.

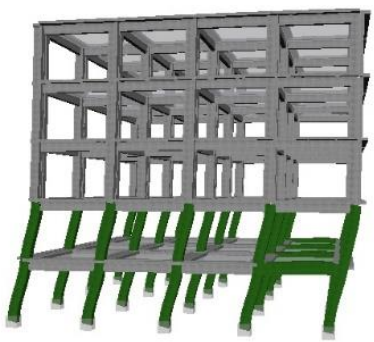

(X Direction)

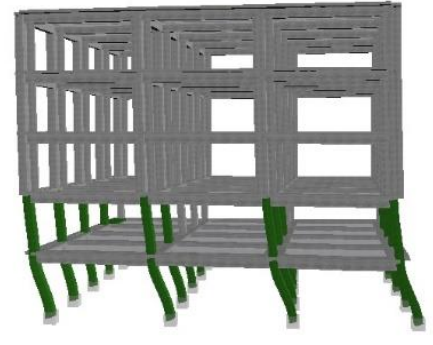

(Y Direction)
Figure 6. Peak displacements and concrete deformations for $\mathrm{X}$ and $\mathrm{Y}$ direction in case of using C14 concrete class for whole building. 
Figure 7 shows the deformation conditions in case of using C25 concrete class in the studied structure.

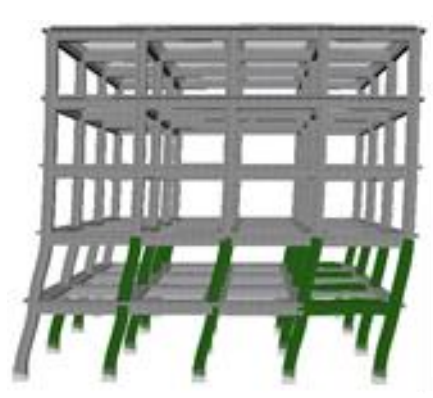

(X Direction)

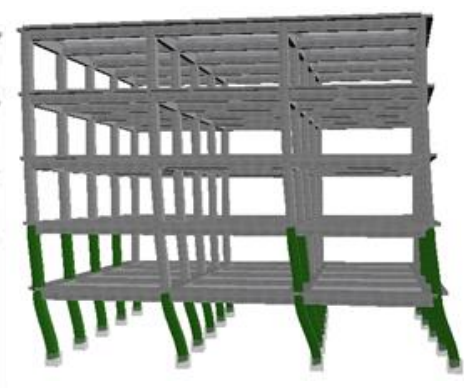

(Y Direction)
Figure 7. Peak displacements and concrete deformations for $\mathrm{X}$ and Y direction in case of using C25 concrete class for whole building.

Figure 8 shows the deformation conditions in the case of using C14 concrete in the first two floors and using C25 concrete in the other floors.

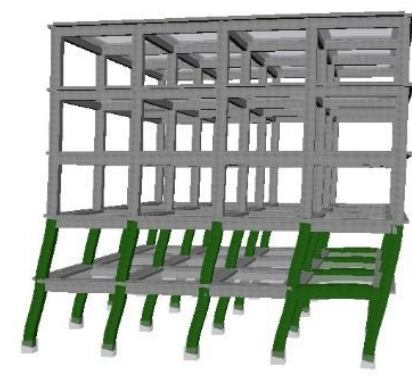

(X Direction)

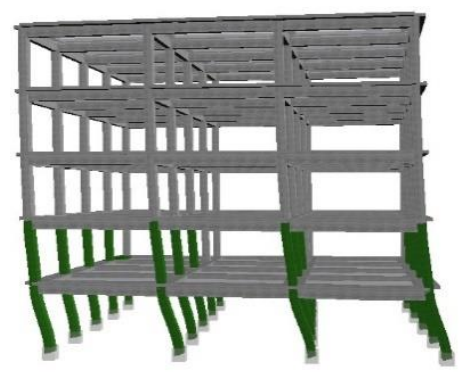

(Y Direction)
Figure 8. Peak displacements and concrete deformations for $\mathrm{X}$ and $\mathrm{Y}$ direction in case of using C14 concrete class for 2 stories and C25 other 3 stories.

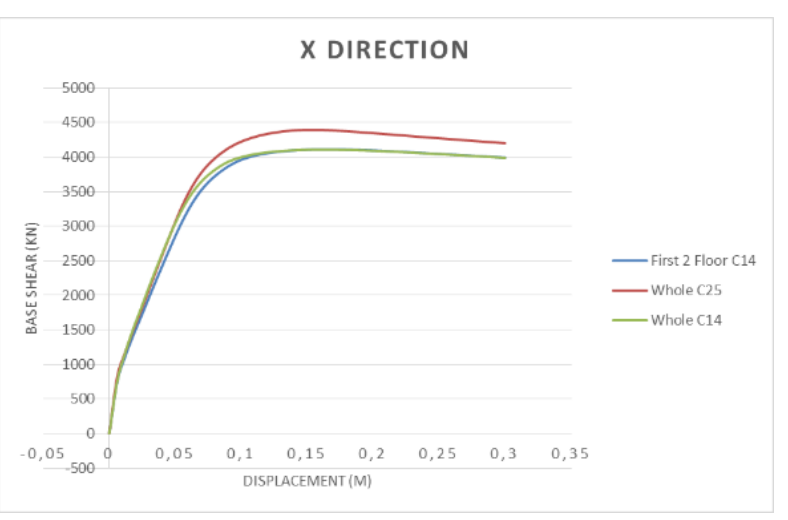

Figure 9. Static pushover curves for $\mathrm{X}$ direction

The static pushover curves obtained due to the variation of the concrete strength between the stories are obtained separately for both directions. The curves obtained in the $\mathrm{X}$ direction are shown in Figure 9; the curves obtained in the $Y$ direction are shown in Figure 10.

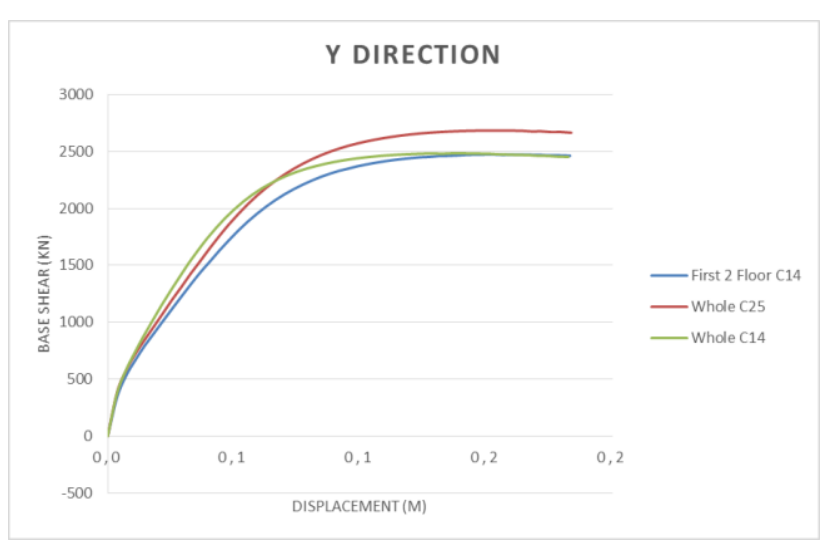

Figure 10. Static pushover curves for $Y$ direction

The peak displacement values and the base shear force values in the $\mathrm{X}$ direction obtained in the case of using different concrete classes between the storeys are shown in Table 1.

Table 1. Base shear and maximum displacements for $\mathrm{X}$ direction

\begin{tabular}{|c|c|c|}
\hline \multicolumn{3}{|c|}{ Max. Displacement - Base Shear for X Direction } \\
\hline Concrete Class & Base Shear(kN) & Displacement(m) \\
\hline C14 & 3988,652 & 0,300 \\
\hline C25 & 4200,286 & 0,302 \\
\hline C14-C25 & 3991,203 & 0,300 \\
\hline
\end{tabular}

The peak displacement values and the base shear force values in the $\mathrm{Y}$ direction obtained in the case of using different concrete classes between the storeys are shown in Table 2 .

Table 2. Base shear and maximum displacements for $Y$ direction

\begin{tabular}{|c|l|c|}
\hline \multicolumn{3}{|c|}{ Max. Displacement - Base Shear for Y Direction } \\
\hline Concrete Class & Base Shear(kN) & Displacement $(\mathrm{m})$ \\
\hline C14 & 2452,326 & 0,183 \\
\hline C25 & 2664,642 & 0,184 \\
\hline C14-C25 & 2462,299 & 0,183 \\
\hline
\end{tabular}




\section{Conclusions}

Only the first floors of some buildings are being constructed at the beginning due to various reasons. In time, when such structures become inadequate to serve the purposes, additional floors are being built, controlled or uncontrolled. Additional floors are built directly on the previously built structure. In this study, the effect of the difference of the concrete quality used in the later constructed floors and the concrete quality used in the original building on the structural earthquake performance was investigated. For this purpose, low strength concrete is used for the first floors for the RC building, and higher strength concrete is used for the additional floors. The reason for this is the developments in concrete technology. In general, concrete is poured into the hands or by concrete mixer in the first floors of such structures. With the widespread production and use of ready mixed concrete, these types of concrete are used in additionally constructed floors. As a result of it, inter-storey concrete strengths would be different. The purpose of this study is to determine the effect of this differentiation on structural earthquake behavior. There are many buildings built in this way in Turkey. It is important to examine earthquake behavior of such structures.

Static pushover curves have obtained for a RC building which chosen as an example. Changing of inter-storey concrete quality reduces the base shear forces in both directions. However, no significant changes of peak displacement were observed.

In general, damages due to earthquakes occur on the ground floors of the structures. Concrete strength starts to change on the first floors. So the defense mechanism of such structures would be weaker.

It is obvious that the earthquake safety in the structures where the concrete strength changed between the floors is lower than the constructed by using the concrete strength of the same quality structures. In this context, while constructing buildings, continuity should be obtained in terms of material strength.

It is important to avoid any negativities that would make the structure earthquake defense mechanism weaker in terms of to reduce losses in a possible earthquake. For this purpose, the existing structures should be evaluated in terms of urban transformation and necessary actions should be taken for buildings that do not have sufficient earthquake safety. For the new buildings, the related regulations and standards should be closely followed and the necessary controls must be made from the project phase to the end of the construction period. The persons, institutions and organizations that will carry out the control processes while the constructions are being built should do this with precision. The increase in concrete quality increases the base shear force and the peak displacement amount that can be carried. The change of concrete quality changed the peak displacement values in both directions. Equal strength at every point of construction will prevent weak nodes in construction. Concrete class should be used in the same quality as the structure as much as possible. In this study calculations were made for 5 stories. With the increase number of stories, the differences will be more significant.

\section{References}

Aydınoğlu, M. N., 2007. A response spectrum-based nonlinear assessment tool for practice: incremental response spectrum analysis (IRSA), ISET Journal of Earthquake Technology, 44(1), 169192.

Computers and Structures, 2011. Sap2000 15.1.0. Berkeley.

DBYBHY, 2007. Deprem Bölgelerinde Yapılacak Binalar Hakkında Yönetmelik. Tc Çevre Ve Şehircilik Bakanlığı, Afet İşleri Genel Müdürlüğü, Deprem Araștırma Dairesi.

Doran, B., Akbaş, B., Sayım, İ., Fahjan, Y., and Alacalı, S.,N., 2011. Uzun periyotlu bir yapıda yapısal sağlık izlemesi ve deprem performansının belirlenmesi, 1. Türkiye Deprem Mühendisliği ve Sismoloji Konferansı,Ankara

Ersoy, U. and Özcebe, G. 2007. Betonarme: temel ilkeler, TS-5002000 ve Türk deprem yönetmeliğine (1998) göre hesap. Evrim Yayınevi.

Estêvão, J. M., and Oliveira, C. S. 2015. A new analysis method for structural failure evaluation. Engineering Failure Analysis, 56, 573584.

Inel, M., and Meral, E. 2016. Seismic performance of RC buildings subjected to past earthquakes in Turkey. Earthquakes and Structures, 11(3), 483-503.

Inel, M., Bilgin, H., and Özmen, H. B. 2007. Orta Yükseklikteki Betonarme Binaların Deprem Performanslarının Afet Yönetmeliğine Göre Tayini. Pamukkale Üniversitesi Mühendislik Bilimleri Dergisi, 13(1), 81-89.

Ișık, E., 2016 a. Effects of Material Strength on Structural Performance of Damaged RC Buildings., Bitlis Eren Univ J Sci \& Technol 6 (1), 22-25,

Işık, E., 2016 b. Consistency of the rapid assessment method for reinforced concrete buildings, EarthquakesandStructures,Vol. 11, No. 5(2016) 873-885, ,

Krawinkler, H., and Seneviratna, G. D. P. K. 1998. Pros and cons of a pushover analysis of seismic performance evaluation. Engineering structures, 20(4), 452-464.

Kutanis, M., and Boru, O.,E., 2014. The need for upgrading the seismic performance objectives, Earthquakes and Structures, 7(4), 401-414.

SeismoStruct v6.5 2013, A computer program for static and dynamic nonlinear analysis of framed structures. Seismosoft

Uğurlu, A., 2013. Depremde beton ve davranışı. İmo Mühendislik Haberleri 476: 58, 